\title{
29. PROGRESSIVE ALTERATION OF THE OCEANIC CRUST
}

\author{
Roger Hart, Physical Research Laboratory, Ahmedabad 380009, India
}

\section{INTRODUCTION}

This chapter presents a synthesis of the main alteration characteristics of basalt from DSDP basement sites, with the aim of evaluating the factors regulating the rate, intensity, and depth of alteration of the oceanic crust. Progressive chemical alteration of volcanic basement by seawater was noted by Hart (1970) who showed that the $\mathrm{H}_{2} \mathrm{O}$ contents and iron oxidation ratios of dredged samples increase with distance from major spreading ridges. Christensen and Salisbury (1972) suggested that chemical leaching of oceanic crust by seawater decreased its capacity to transmit sonic waves. Cox et al. (1972) suggested that seawater oxidation of titanomagnetite would cause a decrease in the intensity of remnant magnetism of the oceanic crust with distance from spreading centers. In this review, sonic velocity, $\mathrm{H}_{2} \mathrm{O}$ content, and the iron oxidation ratio will be used as the main indicators of seawater alteration of basement rock.

\section{DEPTH OF ALTERATION}

Previous estimates of the depth of seawater alteration vary considerably. The results of $\mathrm{O}^{18} / \mathrm{O}^{16}$ measurements on dredged greenstones by Muehlenbachs and Clayton (1972) suggest that seawater percolates through oceanic crust near the ridge axis to sufficient depth to react in the greenschist facies. Cox et al. (1972) estimate that alteration of the oceanic crust to a depth of 500 meters could decrease the intensity of the natural remnant magnetism of volcanic basement sufficiently to account for the observed drop in intensity of magnetic anomalies on the flanks of spreading ridges.

Hart (1973) suggested that the low-velocity cap on oceanic layer II, as measured in some sonobuoy refraction experiments may be indicative of alteration processes in the upper $0.5 \mathrm{~km}$ of layer II. He also pointed out that low temperature weathering of basalts over one-third the sea-floor area could absorb the stream supply of potassium to the oceans.

Christensen (1973), extrapolating the sonic-velocity data on the long basement core from Site 257, suggested that weathering may be common to depths of the order of 100 meters. This estimate is supported by the sonicvelocity data on other DSDP long basement cores (Figure 1) when eye-fit curves are extrapolated to the depth at which the sonic velocity equals that of fresh basalt. The extrapolated velocity estimates must be taken with caution because of the possible presence of young, unweathered sills (as at Site 261). Nonetheless, a general flattening of the sonic velocity versus depth gradient with age seems to be indicated. Site 286 appears to represent a unique case of intense alteration in relatively young crust. Extrapolation of the velocity ver- sus depth curve at Site 286 would suggest over 200 meters of alteration, but this extrapolation is risky because of the steep velocity gradient and possible presence of sills.

In general, the sonic-velocity data routinely gathered on basement materials onboard Glomar Challenger (Figure 1) suggest that basement alteration to depths of up to 100 meters may be commonly encountered in older sections of the oceanic crust, and that alteration to depths of 200 meters may be occasionally encountered.

\section{RATE OF ALTERATION}

Based on a study of ship-to-ship refraction data on oceanic layer II, Hart (1973) estimated the rate of decrease of sonic-velocity in the oceanic crust to be $0.022 \mathrm{~km} / \mathrm{sec} / 10^{6} \mathrm{yr}$. Christensen and Salisbury (1973), measuring the sonic velocity in DSDP samples, calculated a rate of decrease of $0.018 \mathrm{~km} / \mathrm{sec} / 10^{6} \mathrm{yr}$ near the basement-sediment contact. A plot of the average sonic velocities in DSDP deep basement penetration cores versus age (Figure 2) indicates some agreement with previous estimates of rates of alteration for the younger sites, but a large disparity for older sections of the oceanic crust. The DSDP data suggest that the rate of alteration may decrease with time; however, other factors, such as the sill capping at Site 261, and progressive compaction of old oceanic crust by an increasing load of sediment overburden and water column must be considered.

\section{FACTORS REGULATING ALTERATION}

It is obvious from Figure 1 that all DSDP sites have not been altered at the same rate. An attempt to delineate factors regulating the rate of alteration was made by grouping basement sites according to their tectonic setting (Figure 3) and modes of emplacement (Figure 4). The water contents and iron oxidation ratios of samples from these sites are plotted as a function of age in Figures 5 and 6, respectively, both of which show a steady increase with age despite an increasing thickness of sediment cover. One sample from a lava flow interbedded in sediment is highly altered. These observations indicate that sediment cover does not prohibit seawater access to volcanic basement rocks.

Samples cored on high plateaus, aseismic ridges, and seamounts generally have higher water contents than samples of the same age taken from abyssal regions. The reason may be that seawater has greater access to features of high relief above the sea floor.

Samples of massive sills and lava flows generally have lower water contents than extrusive pillow lavas of the same age. In the case of sills, the reason may be that they have been emplaced more recently, but the effect is noted for massive lava flows also, suggesting that 


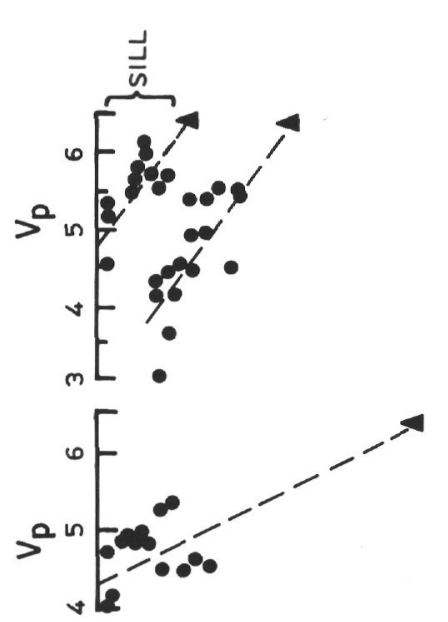

ले خें

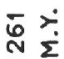

崩踪

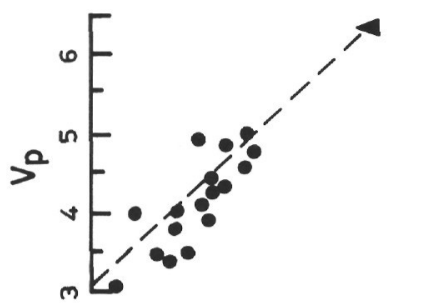

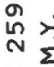
แํำ

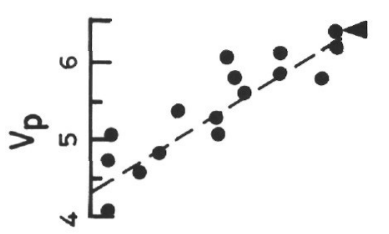

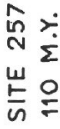

屴
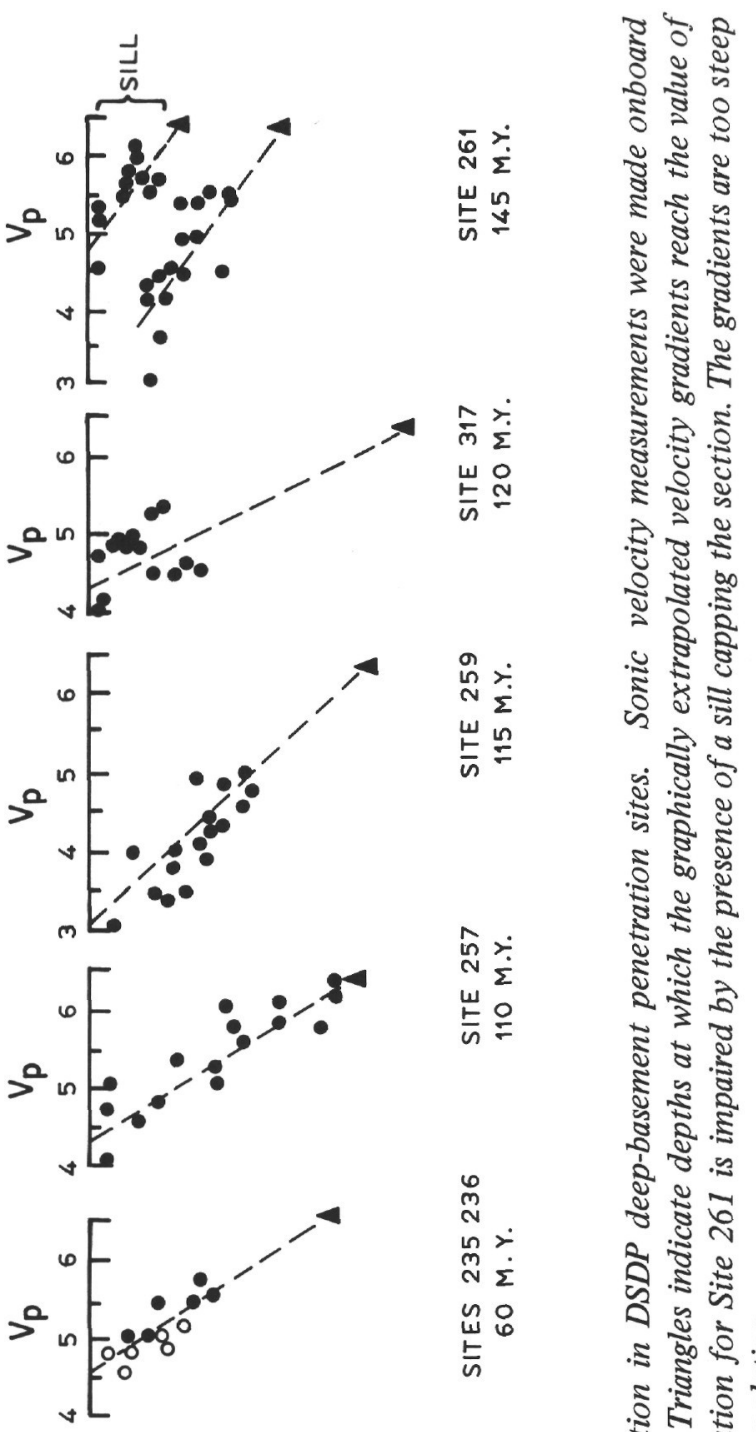

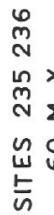

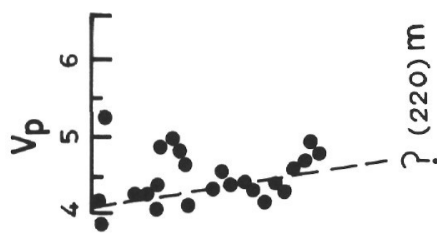

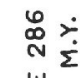

屴 웅

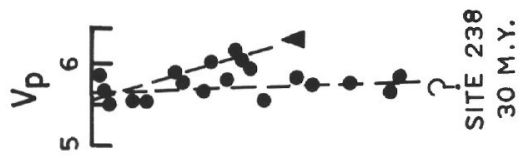

$\stackrel{20}{\square}$

$\sum_{0}^{\infty}$

in $L$

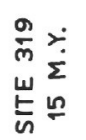

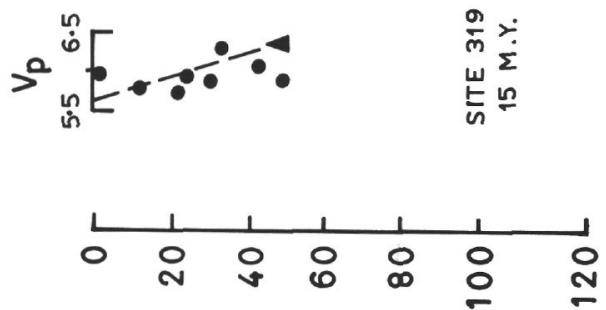

( $S Y \exists \perp \exists W$ )

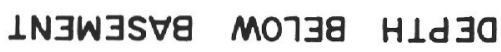

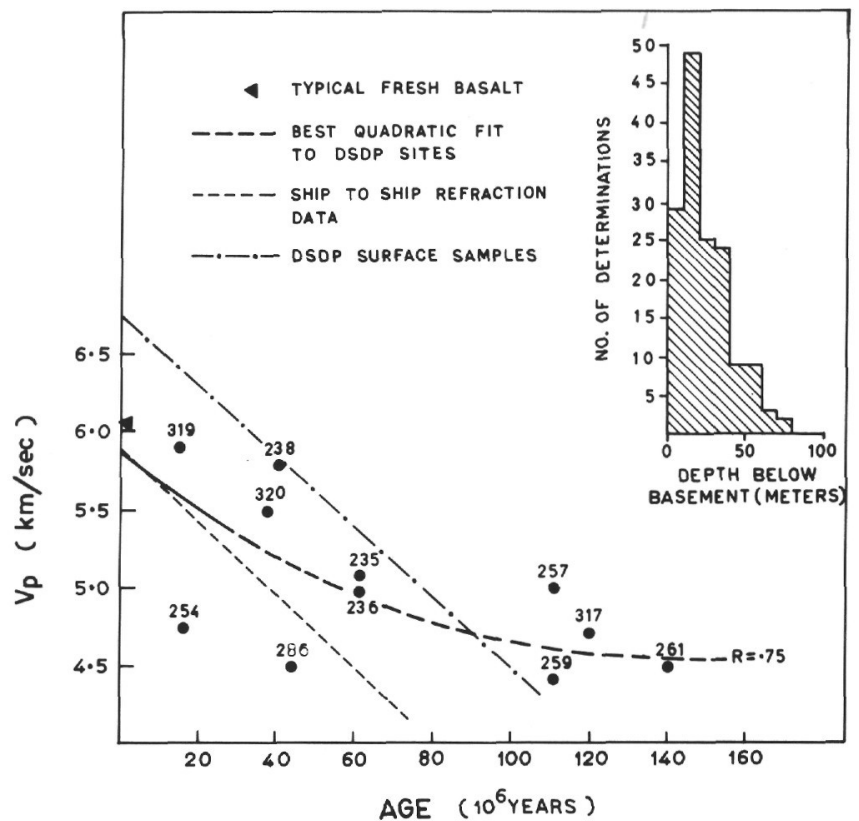

Figure 2. Average sonic velocity of DSDP deep-basement penetration cores as a function of age. Sonic velocity measurements were made onboard Glomar Challenger using the Hamilton frame at $1 \mathrm{~atm}$. The histogram insert gives the frequency of basement penetration depths from which the measured cores were taken. The velocity gradient from ship-to-ship refraction data is from Hart (1973). The velocity gradient for DSDP basement surface samples is from Christensen and Salisbury (1973, fig. 4). Measurements were made at $0.5 \mathrm{~kb}$, so the gradient should lie above the one derived from Hamilton frame measurements at $1 \mathrm{~atm}$, as it does for ages less than 100 m.y.

seawater has limited access to the interiors of massive volcanic bodies due to a lack of cooling joints and brecciated zones.

\section{MULTIVARIATE ANALYSIS}

The dependence of sonic velocity, $\mathrm{H}_{2} \mathrm{O}$ content, and iron oxidation ratio on the age of the oceanic crust and the depth of drill penetration into crystalline basement was determined by multiple regression analysis. The results show significant correlations (Table 1).

The rate of decrease of sonic velocity at the basementsediment contact as determined by this method is 0.007 $\mathrm{km} / \mathrm{sec} / 10^{6} \mathrm{yr}$. This rate is significantly lower than Hart's (1973) estimate of $0.022 \mathrm{~km} / \mathrm{sec} / 10^{6}$ and Christensen and Salisbury's (1973) estimate of 0.018 $\mathrm{km} / \mathrm{sec} / 10^{6} \mathrm{yr}$. The reason may be that this study contains a larger number of samples of old oceanic crust (greater than 80 m.y.) than the previous studies. Perhaps basalt rich in clay minerals is significantly compacted by the increased load of sediment and water column overlying old oceanic crust. Such a compaction may be responsible for an increase in density and therefore sonic velocity in old samples and give an erroneous impression of a decrease in the rate of seawater alteration. 


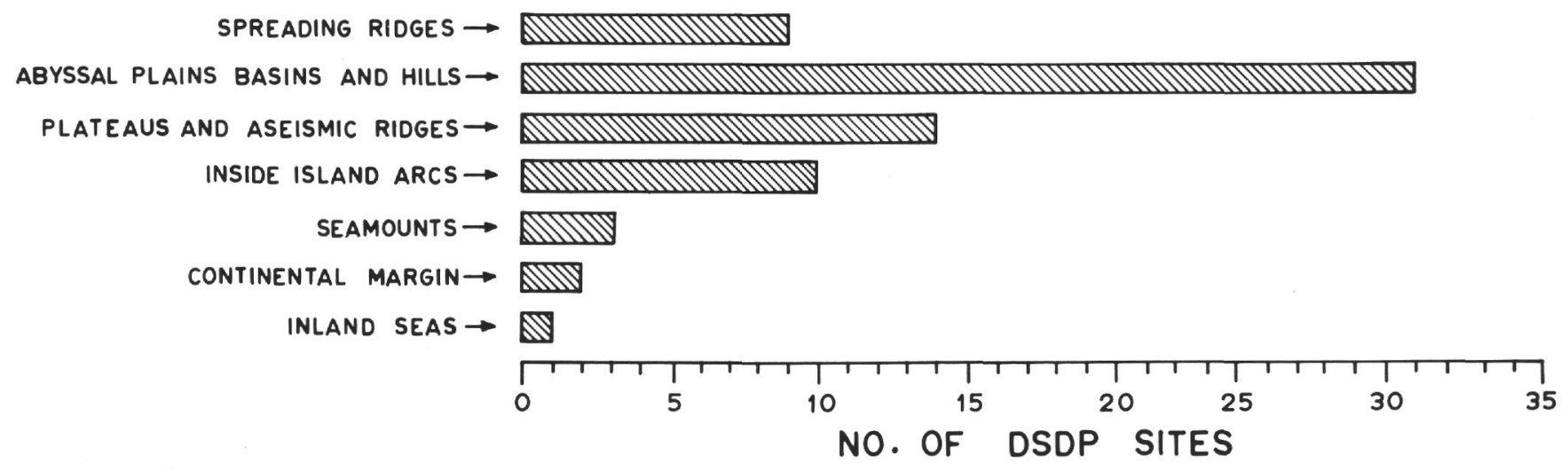

Figure 3. Histogram depicting tectonic settings of DSDP basement sites used in this study.

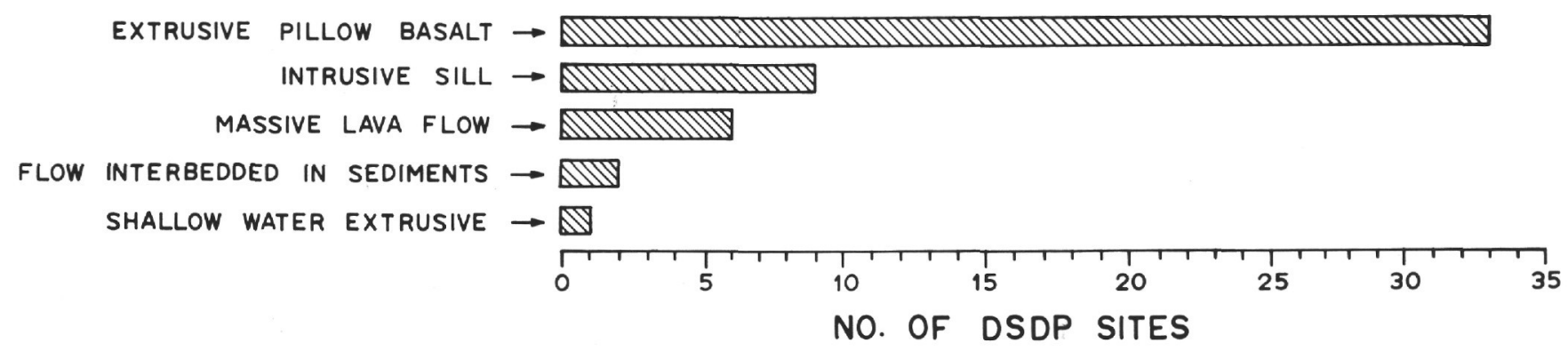

Figure 4. Histogram depicting modes of emplacement of DSDP basalts used in this study.

The depth of basement penetration at which fresh basalt would be encountered can be calculated at any given age of oceanic crust by dividing the rate of change of alteration parameters with age by their rate of change with depth. Using some velocity and iron oxidation ratios, the calculated depth of alteration at 100 m.y. is 65 meters. The calculated depth using the $\mathrm{H}_{2} \mathrm{O}$ contents is 100 meters. These results are in general agreement with estimates of alteration depth derived by graphically extrapolating the down-hole sonic-velocity data.

A further multiple regression program was run using water column thickness and sediment thickness in addition to age and basement penetration depth. The results are given in Table 2 .

In comparison to the results given in Table 1, the statistical significance (based on the F ratio test) of the equation for sonic velocity decreased using the water column thickness and sediment thickness as additional parameters. Quite surprisingly, the significance of the $\mathrm{H}_{2} \mathrm{O}$ equation greatly improved because of a marked positive correlation between $\mathrm{H}_{2} \mathrm{O}$ content and sediment thickness. The equation for the iron oxidation ratios slightly improved with a strong positive correlation of increasing oxidation of iron with sediment thickness. The results indicate the sediment overburden does not dampen the reaction between seawater and the oceanic crust. The improvement in statistical significance of the equation for $\mathrm{H}_{2} \mathrm{O}$ contents might suggest overburden pressure enhances the alteration reaction.

The depth of alteration in 100-m.y. oceanic crust was calculated using the equation represented in Table 2 for each of the alteration parameters by assigning appropriate water column and sediment thicknesses. The alteration depths are almost double those calculated from the relation in Table 1 . This is mainly because the calculated rates of alteration are higher. In particular, the rate of decrease of sonic velocity is more in line with previously published estimates.

In general the depth of alteration calculated from the rate of change of $\mathrm{H}_{2} \mathrm{O}$ contents of oceanic basalt is higher than the depths of alteration calculated from the rate of change of sonic velocities or iron oxidation ratios. As mentioned previously, the rate of change of sonic velocity may give erroneously low estimates due to the effects of compaction in old oceanic crust. The rate of change of iron oxidation ratios may give lower rates of alteration than the $\mathrm{H}_{2} \mathrm{O}$ contents because of unavailability of oxygen in seawater circulating through the oceanic crust.

\section{CONCLUSIONS}

The upper 100 to 200 meters of oceanic crust appear to have undergone low temperature alteration, particularly in old regions. Based on the data available, the rate and depth of alteration is not known within a factor of three. Sediment cover does not prohibit circulation of seawater in the oceanic crust. Areas of high relief, such as plateaus, aseismic ridges, and seamounts are more likely to be altered than abyssal regions. Massive sills and flows may locally impede the free circulation of seawater and retard the alteration process. Increased pressure due to increase of water column and sediment overburden may accelerate the alteration reactions. The depth of alteration calculated from the rate of change of $\mathrm{H}_{2} \mathrm{O}$ content of the oceanic crust is significantly higher that the depths of alteration calculated from the rate of change of sonic velocity or iron oxidation ratio. Compaction of altered basement in old regions may retard 

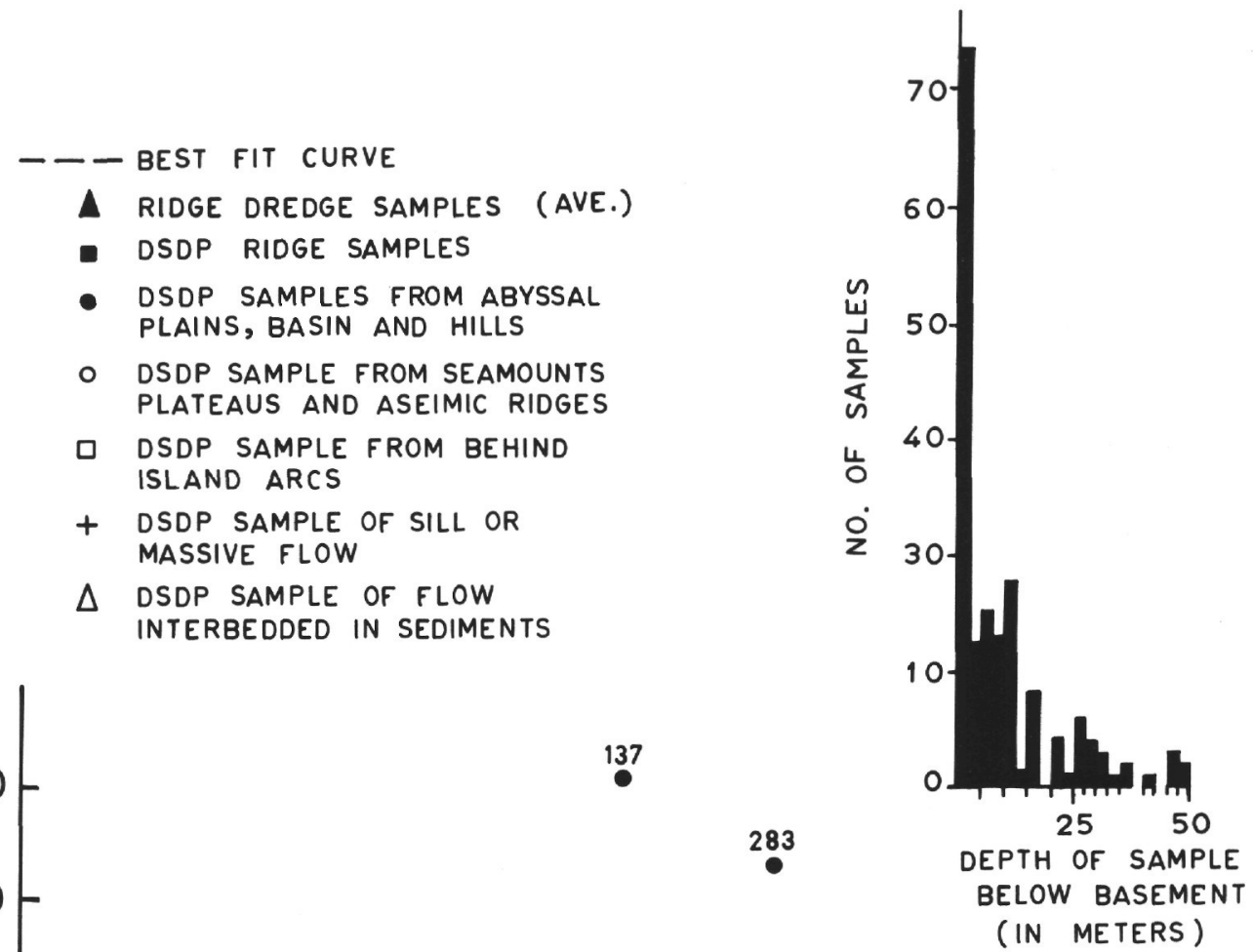

Figure 5. Average $\mathrm{H}_{2} \mathrm{O}$ contents of basalts from DSDP basement sites as a function of age. The histogram insert indicates the frequency of basement penetration depths from which the samples were taken. The average sediment thicknesses for the sites are indicated in the bottom graph. 


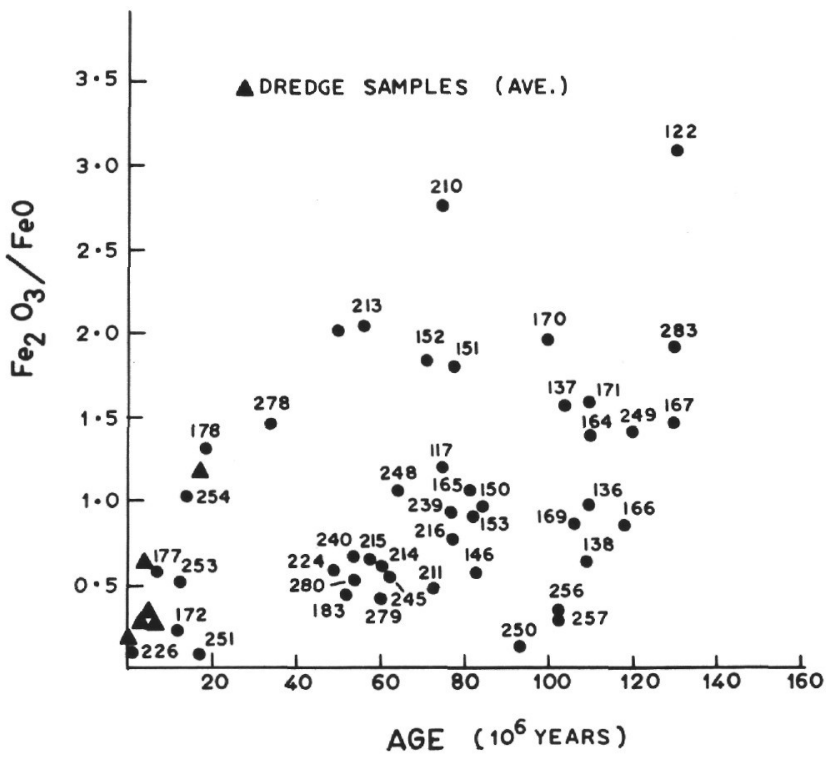

Figure 6. Average $\mathrm{Fe}_{2} \mathrm{O}_{3} / \mathrm{FeO}$ ratios of basalts from $\mathrm{DSDP}$ basement sites as a function of age. the rate of change of sonic velocity. Due to scarcity of oxygen in seawater circulating through the oceanic crust, the oxidation of iron minerals may not be as extensive as the formation of clay minerals from silicates.

\section{REFERENCES}

Christensen, N.I., 1973. Seismic structure of the upper portion of layer II: Am. Geophys. Union Trans., v. 54, p. 1033.

Christensen, N.I. and Salisbury, M.H., 1972. Sea floor spreading, progressive alteration of layer 2 basalts, and associated changes in seismic velocities: Earth Planet. Sci. Lett., v. 15, p. 367-375.

1973. Velocities, elastic moduli and weathering, age relations for Pacific layer II basalts: Earth Planet. Sci. Lett., v. 15 , p. $367-375$.

Cox, A., Blakely, R.J., and Phillips, J.D., 1972. (Abstract): Am. Geophys. Union, v. 53, p. 974.

Hart, R.A., 1970. Chemical exchange between seawater and deep ocean basalts: Earth Planet. Sci. Lett., v. 9, p. 269279.

1973. A model for chemical exchange in the basaltseawater system of oceanic layer II: Canadian J. Earth Sci., v. 10 , p. $799-816$.

Muehlenbachs, K. and Clayton, R.N., 1972. Oxygen isotope geochemistry of submarine greenstones: Canadian J. Earth Sci., v. 9, p. 172-182.

TABLE 1

Results of Multivariate Analysis Study on the Dependence of Sonic Velocities, $\mathrm{H}_{2} \mathrm{O}$ Contents, and Iron Oxidation Ratios of Oceanic Basalt on Basement Age (as Determined Paleontologically on Oldest Overlying Sediment) and Depth of Drill Penetration Into Basement

\begin{tabular}{|c|c|c|c|c|c|c|c|c|}
\hline & \multirow{2}{*}{$\begin{array}{l}\text { No. of } \\
\text { Obser- } \\
\text { vations }\end{array}$} & \multirow{2}{*}{$\begin{array}{c}\text { Correlation } \\
\text { Coefficient } \\
\text { for all } \\
\text { Variables }\end{array}$} & \multirow{2}{*}{$\begin{array}{c}F \text { Ratio } \\
\text { for all } \\
\text { Varia- } \\
\text { bles }^{\mathrm{a}}\end{array}$} & \multicolumn{2}{|c|}{$\begin{array}{l}\text { Change per } \\
100 \text { m.y. Age }\end{array}$} & \multicolumn{2}{|c|}{$\begin{array}{c}\text { Change per } 10 \mathrm{~m} \\
\text { Basement } \\
\text { Penetration }\end{array}$} & \multirow[t]{2}{*}{$\begin{array}{l}\text { Calculated } \\
\text { Depth of } \\
\text { Alteration } \\
\text { in } 100-\mathrm{m} . y . \\
\text { Old Oceanic } \\
\text { Crust (m) }\end{array}$} \\
\hline & & & & Coefficient & $T$ test $^{\mathrm{b}}$ & Coefficient & $T$ test $^{\mathrm{b}}$ & \\
\hline $\mathrm{V}_{\mathrm{p}}$ & 151 & 0.42 & 15.66 & -.65 & -3.92 & 0.10 & 2.90 & 65 \\
\hline$\% \mathrm{H}_{2} \mathrm{O}$ & 193 & 0.46 & 25.83 & 2.59 & 7.10 & -.25 & -1.86 & 104 \\
\hline $\mathrm{Fe}_{2} \mathrm{O}_{3} / \mathrm{FeO}$ & 160 & 0.41 & 15.35 & 0.77 & 5.51 & -.12 & -2.29 & 64 \\
\hline
\end{tabular}

${ }^{\text {a }} F$ ratio shows significance at $99 \%$ confidence level above 3.78 .

$\mathrm{b}_{T}$ test shows significance at $99 \%$ confidence level above 2.58 and $95 \%$ confidence level above 1.96 .

TABLE 2

Results of Multivariate Analysis Study on the Dependence of Sonic Velocities, $\mathrm{H}_{2} \mathrm{O}$ Contents, and Iron Oxidation Ratios of Oceanic Basalt on Water Column Thickness, Sediment Thickness, Basement Age, and Depth of Drill Penetration Into Basement

\begin{tabular}{|c|c|c|c|c|c|c|c|c|c|c|c|c|c|}
\hline & \multirow{2}{*}{$\begin{array}{l}\text { No. of } \\
\text { Obser- } \\
\text { vations }\end{array}$} & \multirow{2}{*}{$\begin{array}{c}\text { Correlation } \\
\text { Coefficient } \\
\text { for All } \\
\text { Variables } \\
\end{array}$} & \multirow{2}{*}{$\begin{array}{c}F \text { Ratio }^{\mathrm{a}} \\
\text { for All } \\
\text { Variables }\end{array}$} & \multicolumn{2}{|c|}{$\begin{array}{c}\text { Change per } 1000 \mathrm{~m} \\
\text { Water Column } \\
\text { Thickness }\end{array}$} & \multicolumn{2}{|c|}{$\begin{array}{l}\text { Change per } 100 \mathrm{~m} \\
\text { Sediment } \\
\text { Thickness }\end{array}$} & \multicolumn{2}{|c|}{$\begin{array}{l}\text { Change per } \\
100 \mathrm{~m} . \mathrm{y} . \\
\text { Basement Age }\end{array}$} & \multicolumn{2}{|c|}{$\begin{array}{c}\text { Change per } 10 \mathrm{~m} \\
\text { Basement } \\
\text { Penetration }\end{array}$} & \multirow{2}{*}{$\begin{array}{c}\text { Total } \\
\text { Change } \\
\text { per } 100 \\
\text { m.y.c }\end{array}$} & \multirow{2}{*}{$\begin{array}{l}\text { Calculated } \\
\text { Depth of } \\
\text { Alteration } \\
\text { in } 100-\mathrm{m} . y . \\
\text { Old Crust (m) }\end{array}$} \\
\hline & & & & Coefficient & $T$ Test $^{\mathrm{b}}$ & Coefficient & $T$ Test $^{b}$ & Coefficient & $T$ Test $^{b}$ & Coefficient & $T$ Test $^{\mathrm{b}}$ & & \\
\hline $\mathrm{V}_{\mathrm{p}}(\mathrm{km} / \mathrm{sec})$ & 151 & 0.50 & 11.8 & -.11 & 1.65 & -.11 & -3.69 & -.56 & -3.38 & .11 & 3.18 & -1.11 & 103 \\
\hline$\% \mathrm{H}_{2} \mathrm{O}$ & 193 & 0.65 & 31.32 & 0.17 & 0.16 & 0.53 & 7.40 & 0.90 & 1.97 & -.17 & -1.30 & 2.83 & 166 \\
\hline $\mathrm{Fe}_{2} \mathrm{O}_{3} / \mathrm{FeO}$ & 160 & 0.56 & 17.79 & 0.13 & 3.43 & 0.15 & 5.43 & 0.08 & 0.47 & -.10 & -2.04 & 0.79 & 79 \\
\hline
\end{tabular}

${ }^{a} F$ ratio shows significance at $99 \%$ confidence level above 3.78 .

$\mathrm{b}_{T}$ test shows significance at $99 \%$ confidence level above 2.58 and $95 \%$ confidence level above 1.96 .

${ }^{c}$ Based on a change of 2000-meter water column and 300-meter sediment thickness per 100 m.y. 